Reference:

Muñoz-Basols, Javier and Danica Salazar. 2016. "Cross-Linguistic Lexical Influence between English and Spanish." Spanish in Context 13.1: 80-102. Doi: 10.1075/sic.13.1.04mun.

\title{
Cross-Linguistic Lexical Influence between English and Spanish
}

\author{
Javier Muñoz-Basols and Danica Salazar
}

This article focuses on the cross-linguistic lexical influence between English and Spanish. We begin by redefining the concept of cross-linguistic lexical influence as the impact that two or more languages have on each other's vocabulary. We then present a brief chronological survey of Hispanicisms in English and Anglicisms in Spanish, taking the Oxford English Dictionary (OED) and the Diccionario de la lengua española (DRAE) as the main sources, and examine some of the factors that affect the patterns of word interchange between these two languages. We argue that the historical and social milieu, mass media, information technology, prevailing attitudes to foreignisms, and the stance taken by dictionaries and official linguistic policy condition which words are borrowed, affect the phonological, orthographic and semantic forms of these borrowings, and impact the degree of their integration in the receiving language. The present study is the first to offer a crosslinguistic (bilateral) perspective on lexical borrowing, a novel approach that is of particular interest given the contrasting philosophical differences governing language policy and lexicographic traditions in English and Spanish. It demonstrates the importance of adopting a comparative approach in the study of lexical influence between languages.

Keywords: cross-linguistic lexical influence, Anglicisms, Hispanicisms, lexical borrowing, lexicography, comparative approach, speakers' attitudes, sociolinguistics, language contact, language policy, Oxford English Dictionary, Diccionario de la lengua española

\section{Introduction}

Contact among speakers of different languages inevitably leads to a certain degree of crosslinguistic influence, its most obvious and immediate manifestation being at the lexical level. While lexical borrowing, i.e., the incorporation of words from foreign sources, is a completely natural linguistic phenomenon, it has always been the subject of considerable controversy. This can be best illustrated through the work of the Chilean writer Pedro Lira Urquieta, who in his 1973 Estudios sobre vocabulario discussed the debate around the use of the verbs aparcar, estacionar and parquear, all of which mean 'to park' in Spanish:

Los autores de Diccionarios de Americanismos, Santa María y Morinigo entre ellos, sostienen que en los planes americanos de lengua española se habla de 'aparcar' y 'aparcamiento' y de 'parquear' y 'parqueo.' Don Ricardo Alfaro en su Diccionario de Anglicismos se indigna de tal empleo y defiende el uso de los verbos 'estacionar' y 'parar.' El ecuatoriano Toscano celebra que se empleen ahora estos vocablos tomados del inglés porque antes, según dice, en Ecuador sólo se hablaba de 'parking' (1973, 114). 
Lira Urquieta's words reveal the two polar attitudes that speakers have traditionally displayed regarding lexical borrowing in a language. As he states in the extract above, there are those who believe that the encroachment of alien words not only hinders understanding and solidarity among speakers, but also threatens the purity of a language by taking away its uniqueness and limiting its ability to create new words using its own linguistic resources. Some language purists have gone so far as to warn that foreign borrowing can undermine a nation's identity and cultural heritage by putting the recipient language in an inferior position vis-à-vis the donor language. On the other hand, there are those who favour the borrowing of words from other languages, celebrating loanwords as an enrichment of vocabulary that results in greater precision and elegance of expression. These people maintain that foreign influences make one's language receptive to new ideas and spheres of knowledge, thereby helping it to keep up with the changing times (for more on the divergent attitudes towards borrowing in Spanish and on linguistic policy, see Rodríguez González 1999, 107-109, Rodríguez Medina 2000, Dworkin 2012, 219-223, and Paffey 2012, and in English, Eggington and Wren 1997, and Guijarro Ojeda and Ruiz Cecilia 2004).

Taking into consideration the impassioned arguments of both sides of this debate, it is evident that lexical borrowing is not a simple linguistic process; rather, it is a highly complex issue conditioned by a variety of cultural factors that are as much social and historical as they are political. In order to identify and understand these various factors, this article will concentrate on the reciprocal lexical influence that exists between two of the most widely spoken languages in the world: English and Spanish. We have specifically chosen to focus on these two languages because of the fact that English and Spanish are in constant contact, particularly so in the last decades, and also because of their fundamentally different attitudes regarding lexical borrowing.

The English lexicon is known for both its flexibility and receptivity to foreign influences, which is probably due in part to the absence of an Academy of the English Language that holds to a unified standard (Payne 2010, 64). Spanish, on the other hand, has always adopted a more conservative stance, given the strict regulation on its word store imposed by both the Real Academia Española (RAE), founded in 1713, and, since 1951, by its global counterpart, the Asociación de Academias de la Lengua Española (ASALE).

Studies investigating lexical borrowing between Spanish and English, either exclusively (Pratt 1980, Lorenzo 1996, Rodríguez González 1996a, 2001, 2002, Medina López 2004) or as part of a larger work (Dworkin 2012, 212-229, Durkin 2014, 364-369, 372-375), have focused entirely on a single direction of loanword transmission, with one language being the source and the other the recipient. The present study is the first to offer a cross-linguistic (bilateral) perspective on lexical borrowing, a novel approach that is of particular interest given the contrasting philosophical differences governing language policy and lexicographic traditions in English and Spanish.

Our aim is to illustrate the influence that both of these languages have exerted on one another at the lexical level at different time periods. In tracing these general patterns of word exchanges between these two languages, we will be able to examine some of the factors that have tended to impact cross-linguistic lexical influence. These include historical events and social conditions; mass media and information technology; the attitude of the public and the academe to foreignisms; and the treatment of Anglicisms and Hispanicisms in the two most authoritative lexicographical works in both languages: the Oxford English Dictionary (OED) and the Diccionario de la lengua española (DRAE). As we will demonstrate, these factors condition which words are borrowed, as well as the phonological, orthographic and semantic forms that they take, and the degree of their integration in the receiving language.

\section{Cross-linguistic lexical influence}


The term "cross-linguistic influence" has traditionally been used in second language acquisition to explain the effect that one's native language has on the acquisition of another language. For this reason, in an attempt to explain some of the aspects affecting the performance of a learner in a foreign language, it has been applied primarily to refer to the phonological, syntactic, morphological and semantic linguistic transfer from one language to another (Sharwood-Smith and Kellerman 1986, Odlin 1989). With the world becoming increasingly multilingual, recent studies have used this very term to focus their attention on third language acquisition, i.e., analysing the influence of previously acquired languages (Cenoz 2000, 2001, Cenoz, Hufeisen, and Jessner 2001, Hulk and Müller 2001, Hall and Ecke 2002, Braunmüller and House 2009).

Given that the term "cross-linguistic influence" emerged from language contact situations at various levels, and considering how its recent use has been applied to multilingual settings, we aim to take a further step in this study. We propose to expand the meaning of the term to refer to the influence two or more languages may exert on one another-but outside of the realm of language acquisition. More specifically, within a more general framework, we will be using the term "cross-linguistic lexical influence" to reflect the impact that borrowed lexical units from one language may have on another language.

Foreign words are constantly being integrated into any speaker's repertoire. These belong in many cases to distinct semantic fields, and their incorporation into the language has in the past been influenced by historical factors, commercial relations between countries, migrations across various cultures, diasporic communities (see David and Muñoz-Basols 2011, xi-xxiv), as well as works of literature. Our constant exposure to new languages and cultures has, in the last decades of the $20^{\text {th }}$ century and beginning of the $21^{\text {st }}$, brought with it an increase in the borrowing of lexical units. We see this in the growing body of neologisms in science, technology, economics and cultural studies, its dissemination often accelerated by the mass media and social networks.

These neologisms, or new lexical units, allow speakers to communicate more effectively in their language, or languages, as they often identify new extra-linguistic realities related to certain specialised fields. Taking English and Spanish as the starting point of our research, we will show that there are important reasons for borrowing and adapting words. Such reasons may range from a desire for greater concreteness and linguistic brevity, or clarity of expression (Rodríguez González 1996b, 118), (e.g., agencia de rating vs. agencia de calificación crediticia), best evidenced in newspaper headlines, such as, "No hubo stay y no hay default" (Lukin 2014, 1), as well as clarification through bilingual use (e.g., Tengo que pagar los taxes vs. Tengo que pagar los impuestos). They may also correspond to the use of foreignness to convey a variety of intentions such as disparagement, emphasis, amusement or trendiness in advertising (e.g., fashionista, el cheapo, Vueling). However, for the message to be accurately retrieved by the listener, these linguistic manoeuvres must fall within the established linguistic and cultural parameters of the language in question.

The present article will analyse cross-linguistic lexical influence using dictionaries and databases as the main data sources. In addition, in view of the time lag involved in the recording of new terms in dictionaries and databases, our analysis of specific examples will also rely on information from the mass media. As we will illustrate, both through a chronological analysis of the interchange of words between English and Spanish, and through some contextualised examples, the study of cross-linguistic lexical influence can help to clarify the reasons for lexical borrowing in a given language, and even contribute to our understanding of some of the distinctive attitudes that speakers manifest in their language usage.

\section{The impact of historical and social factors on cross-linguistic lexical influence}


Some of the most important forces that drive the ebb and flow of loanwords between languages are linked to historical events and social developments, as we shall demonstrate in this brief chronological survey of borrowing between Spanish and English.

The $22^{\text {nd }}$ edition of the DRAE published in 2001 classifies a total of 672 words as borrowed from English. It is important to note that this number does not reflect all borrowings that may have occurred over time but only those that were selected for the most recent edition of the dictionary, most of them as a reflection of current usage. In fact, the dictionary has routinely eliminated Anglicisms from its new editions for various reasons even when they were not obsolete in terms of usage (BILRAE 2013, 6). On the other hand, OED Online's Timeline feature, which enables users to view in graphical form the number of words first recorded by the dictionary from a specific language of origin within different periods, lists a total of 1,743 borrowings from Spanish in the OED as of June 2015. Unlike the DRAE, the OED provides information on the earliest written occurrence of words and illustrates, using authentic quotations, different spellings and uses that a word may have had at various points in time. The OED does not eliminate words, thus showing a more cumulative view of borrowings over its history than the DRAE does.

\section{1. $14^{\text {th }}$ to $17^{\text {th }}$ century: A new world of words}

Lexical borrowing between Spanish and English can be traced back many centuries.

According to the OED, the earliest possible Hispanicisms in English entered the language as early as the 1300s. However, the OED indicates that all $14^{\text {th }}$-century borrowings and most of the $15^{\text {th }}$-century loanwords attributed to Spanish are of uncertain origin, and could have come either from Spanish or from another Romance source, such as Italian or French. Examples of these possible Spanish borrowings are err (1303, 'to go astray,' < errar), jujube (c1400, 'an edible berry-like drupe,' < jujuba) and tenebrous (c1420, 'full of darkness, dark,' < tenebroso). The oldest OED entry with Spanish as its clear immediate source dates to around 1485 , for the word bocasin, referring to a fine, taffeta-like cloth called bocasí in Spanish.

In the $16^{\text {th }}$ and $17^{\text {th }}$ centuries the slow trickle of Hispanicisms into English became a steady stream (Algeo 1996, 19-21; Durkin 2014, 365). Spain's rising dominance in the military, naval, political and economic spheres not only fostered the spread of Spanish words, but its expansion into the New World also resulted in the importation into English of a large number of exotic new flora and fauna terminologies (Algeo 1996, 19-21, Gooch 1996, 234, Durkin 2014, 365).

The OED data show that 250 certain and possible Hispanicisms were incorporated into English in the $16^{\text {th }}$ century, and 313 in the $17^{\text {th }}$ century. Many of these words came directly into British English from the Peninsula. This is especially true of Spanish borrowings of an administrative and military nature, such as adjutant, contraband, embargo, flota (flotilla), and junta. Another prominent group consists of words connected with objects, plants, animals and natural phenomena from the Americas, which travelled from the New World to Spain and then to Great Britain. These include common English Hispanicisms like cacao, guava, hammock, hurricane, iguana, maize and manatee, all of them dating from the $16^{\text {th }}$ century, and themselves loans from Amerindian languages into Spanish, the Nahuatl, Taino and Carib languages being particularly rich sources of Native American vocabulary. A smaller set of New World lexis includes words of purely Hispanic origin like alligator, armadillo, llama and machete.

As regards Anglicisms in Spanish, a very small number of these can be found dating from before the $18^{\text {th }}$ century. Despite thriving commercial relations between England and Spain, there was not enough direct and regular contact between English and Spanish speakers in this early period for English to have had any significant influence on Spanish vocabulary (Dworkin 2012). While a few English loanwords may have entered the Spanish language via 
French prior to the $18^{\text {th }}$ century, none of these terms are of certain English origin. It is, however, believed that the Spanish terms for the cardinal points norte, sur, este and oeste could be the earliest Anglicisms in the language (Rodríguez González 2002, Dworkin 2012, 213).

\section{2. $18^{\text {th }}$ century: Scientific and technical borrowing}

It was not until the 1700s that English linguistic influence began to be felt in Spain as a result of British advances in agriculture, medicine, politics and economics. These new developments led to an increase in translated works from English into Spanish, together with the promotion of the teaching and learning of the English language in Spain. English scientific and technical terminology also assumed a greater importance (Dworkin 2012). Páramo García (2003) provides evidence of Anglicisms in English to Spanish translations published between 1767 and 1800, most of them used as unintegrated foreign words that did not endure in the modern Spanish lexicon. Some of the few Anglicisms from this period that did take root and were given Spanish forms include bote 'small boat,' cuáquero 'Quaker,' pingüino 'penguin,' ponche 'punch, a mixed drink' and ron 'rum.' However, it is uncertain whether these words were absorbed directly from English into Spanish, or if they were brought into the language via French.

The opposite tendency in lexical borrowing from Spanish to English is seen in the $18^{\text {th }}$ century, an age characterized by a marked decrease in the number of English Hispanicisms, as recorded by the OED (Durkin 2014, 365). Algeo (1996, 22-23) suggests that this meagre borrowing may have been a consequence of the OED's relatively limited record of that period. However, Durkin $(2014,307-310)$ argues that this dip in borrowing is a reflection of the $18^{\text {th }}$-century rhetorical and stylistic preference for classicism and clarity, in contrast to the enthusiasm for lexical novelty that characterized the preceding era. Indeed, if one compares the absolute totals of English Hispanicisms in the OED to their number as a proportion of all new words, one can see that the decrease in Spanish borrowings corresponds to an overall decline in foreign borrowings in English during the 1700s (Durkin 2014, 365-366).

As in previous centuries, most of the 153 Spanish loans that the OED traces back to the 1700s are words that are directly associated with Spain (caballero, cedula, hacienda, mantilla, torero) or with Spanish America (alpaca, cordillera, estancia). It was also during the $18^{\text {th }}$ century when words from different Hispanic territories, such as adobe, cigar, patio and poncho, still in common use today, were first noted in English vocabulary.

\section{3. $19^{\text {th }}$ century: From cowboy language to the language of everyday life}

After a century of decline, the following one hundred years witnessed an unprecedented influx of a large number of Hispanicisms into English (Algeo 1996, Durkin 2014, 365). OED evidence shows that 646 words of Spanish origin entered English between 1800 and 1899. What is notable is that during this time the centre of lexical activity shifted from Europe to America, where the westward expansion of the United States, together with the presence of English-speaking settlers in Hispanic areas in the American Southwest, promoted the spread of "cowboy language," exemplified by such words as vaquero (as well as its corruption, buckaroo), bronco, chaps, lasso and rodeo (see Lodares 1996). Whereas prior to the $19^{\text {th }}$ century, most Spanish borrowings made their way into British English from peninsular Spanish, after the $19^{\text {th }}$ century most Hispanicisms consisted of American Spanish words absorbed directly into American English — a change in lexical borrowing patterns that reflects the increasingly important role played by the New World on the global stage (Algeo 1996, 25-26, Gooch 1996, 231). The hundreds of words of Hispanic-American origin from this period represent a variety of semantic fields, ranging from plants and animals (alfalfa, burro, coyote, marijuana) and geological features (arroyo, canyon, loma), to food (cafeteria, 
enchilada, tamale), drink (Cuba libre, curacao, tequila) and entertainment (habanera, piñata).

Meanwhile, in $19^{\text {th }}$-century Europe, Anglicisms in Spanish continued to consist of mostly British English words that pertain to aspects of British life used in literary texts as unincorporated foreignisms. Among the few borrowings from the 1800s that managed to survive into modern-day Spanish are words such as cheque, club, rifle, revólver, túnel and turista. The very word anglicismo was only added to the DRAE in its $11^{\text {th }}$ edition (1869), where it was defined as a "defect" (Dworkin 2012, 216).

It was in the Americas that Anglicisms started to filter into the vocabulary of Hispanophone territories as a direct result of the political influence of the United States in the newly independent republics of Latin America (Dworkin 2012). Various studies offer examples of Anglicisms identified in the writings of Simón Bolívar (boxear, rifle, corporación) (Hildebrandt 1961), in the Spanish used in Cuba (brandi, bul-dog, chequear) (Pichardo 1836 cited in Dworkin 2012, 217), and in the Spanish spoken in Bogotá, Colombia (budin, bistec, tiquete) (Cuervo 1907, 656).

\section{4. $20^{\text {th }}$ and $21^{\text {st }}$ centuries: From popular culture to the influence of the mass media}

Spanish continued to make significant contributions to the English word stock in the $20^{\text {th }}$ century, during which time American Spanish superseded Peninsular Spanish as the prevailing source of Hispanicisms, both in the British and in the American varieties of the language.

Words related to food and drink assumed increasing importance as Latin American ingredients (chipotle, cilantro, jalapeño, tomatillo), specific dishes (burrito, carnitas, fajita, guacamole, seviche, taco) and drinks (mojito, Tia Maria) established themselves in the culinary landscape of North America as well as the rest of the English-speaking world. Other aspects of Hispanic culture in America also made inroads into the English lexis with music and dance terms like cha-cha, conga, mariachi, paso doble and rumba, as well as ethnic designations like Chicano/a, Latino/a and Tejano, becoming part of common vocabulary.

Politics is another important area that gave rise to a variety of new terms such as autogolpe, contra and desaparecido, along with a number of derivations from names of Latin American political figures such as Fidel Castro (Fidelism, Castrism, Castrista), Juan Perón (Peronism, Peronismo, Peronist, Peronista), Augusto Sandino (Sandinist, Sandinista) and Emiliano Zapata (Zapatismo, Zapatista) (Rodríguez González 1995, 424, Cannon 1996, 46). The Spanish -ista suffix soon became so entrenched in English vocabulary that it began to be attached to names of non-Hispanic leaders, among them the term Clintonista for supporters of former US President Bill Clinton, and even to words found outside of the political sphere, such as fashion to form the expression fashionista, which can be used with a tone of derision (see Rodríguez González 1995 for more on this suffix).

Most recently, we have seen that this type of Hispanicism in English has ceased to consist merely of direct appropriations of exotic foreign words, becoming instead creative adaptations of such terms. The reasons behind the incorporation of these lexical influences have also expanded: although most Spanish loanwords perform an ideational function by filling a specific gap in the lexicon, some of the terms that entered the English lexicon in the $20^{\text {th }}$ century have been used as alternatives to equivalent English forms in order to convey a certain stylistic effect. An example of such expressive synonymic use of American Hispanicisms is their use to convey negative, criminal or taboo concepts, e.g., cojones 'balls' and narcotraficante 'drug dealer.' A particularly interesting example is hoosegow ( $<$ Spanish juzgado), which, besides undergoing phonological adaptation into English, also underwent a semantic shift from its original sense, 'court,' to its current meaning, 'prison.' This, according to Rodríguez González, "allows us to imagine the extent and celerity with which 
Mexicans might have been convicted of crime in the past without being conceded the presumption of innocence" (1995, 427-428).

However, not all English Hispanicisms from the New World originate in the Americas. The people of the Philippines, an island country in Southeast Asia that was formerly a colony of both Spain and the United States, use English as a second language while maintaining a high degree of Hispanic influence in the lexis of their local vernaculars. The impact of Spanish on Philippine languages extends to English, as evidenced by the number of lexical items of Spanish origin that are of high currency in Philippine English. These include borrowings like estafa 'embezzlement,' merienda 'afternoon snack,' pandesal 'bread roll,' and poblacion 'principal community of a district;' derivations such as ladronism 'organized resistance to law among natives' and sampaguita 'Arabian jasmine;' as well as hybrid expressions like sala set 'living room furniture,' despedida party 'farewell party' and chicken relleno 'stuffed chicken.'

This brings us to the development of Anglicisms in Spanish during the $20^{\text {th }}$ century. We find a lull in Spanish borrowing from English during the Civil War and the years under the dictatorship of Francisco Franco, largely due to Spain's isolation during this time, and also to the legislation by Franco's government against the use of foreign words, especially in sports. As Rodríguez González (2002) explains, it was during this period that English sports terminology such as match, back and speaker was replaced by their Spanish equivalents: encuentro, defensa and locutor.

It was not until the second half of the $20^{\text {th }}$ century that English borrowings began to filter back into Peninsular Spanish, as a consequence of the presence of US military bases and Anglo-American tourists in Spain. Anglicisms spread through pop music, print media, television, films, and an increased interest in the teaching and learning of English in the country. The mass media made it possible for words to be transmitted through spoken language even without direct contact between Spanish and English speakers. This was promoted by increased literacy among the Spanish population (Dworkin 2012).

As English rapidly consolidated its position as the world's lingua franca, it started to make its mark on the language of young, urban, educated Spanish speakers. One sphere where Spanish Anglicisms are extremely common is that of information technology, where one finds borrowings like browser, chat, cookie, email, Internet and mail, as well as loan translations like cortafuegos 'firewall,' página web 'webpage,' ratón 'mouse' and ventana 'window' (see Jansen 2005), and others of more recent creation which have been included in the $23^{\text {rd }}$ edition of the DRAE, published in October 2014. Examples include nouns like tuiteo, retuiteo, tuitero and the verb tuitear, adaptations that refer to the Twitter online social network. By adapting the original English word to the orthographical conventions of the Spanish language and not allowing it to enter the language with its original spelling *twittear, the RAE is also trying to diminish the impact of this foreign word. At the same time, some other recent adaptations used in written and spoken Spanish like the verbs googlear or guglear, facebuquear and wasapear, derived from the words Google, Facebook and WhatsApp, respectively, have not been included in this latest edition of the DRAE. This highlights the fact that the inclusion of foreign adaptations in the dictionary is subject to a linguistic policy and a decision process, as discussed further in section 4.3.

Economics is another domain in which many terminological terms have been integrated into Spanish from English. We find that certain terms need to be readily available within the language in order to identify a specific linguistic reality. Some of these have been incorporated in the language as calques, e.g., flujo de caja 'cash flow,' prima de riesgo 'risk premium,' fondos buitre 'vulture funds'; or a variety of combinations which may coexist as synonyms, either fully adapted or translated, e.g., for 'credit rating agency' we find agencia de calificación (de riesgos), agencias de clasificación de crédito, agencia de calificación 
crediticia or, for reasons of concreteness, as a hybrid combination of both languages, e.g., agencia de rating.

The ubiquitous presence of English in almost all fields of endeavour has made it the primary source of new loanwords in all varieties of Spanish, as well as in a wide range of domains over and above computing and economics. The lexical influence of English can be seen in the way Spanish speakers of today talk about science, medicine, fashion, tourism, popular culture, and many other aspects of modern life.

A significant development that needs to be highlighted is that, just as American Spanish has become the primary source of Hispanicisms in English, American English is now the origin of most Spanish Anglicisms (Penny 2006). This is a change that can be attributed not only to the global hegemony of the United States, but also to the growing Hispanic presence in the country. Hispanics now form the largest group of immigrants in the U.S., with a population of over 50 million people that has surpassed Spain in the number of Spanish speakers (Dumitrescu 2013, 526; Muñoz-Basols, Muñoz-Calvo y Suárez García 2014, 3). Bilingualism is the current norm among the majority of US Hispanics, and Spanish is now the second most spoken language in the country. This situation of close bilingual contact provides fertile ground for even more lexical interchange between Spanish and English.

\section{Other factors affecting Spanish-English cross-linguistic lexical influence}

We have seen in the previous section how history and social trends have conditioned the interchange of words between Spanish and English. However, there are other factors that have a bearing on cross-linguistic lexical influence between the two languages. In this section, we will focus on each of these factors and describe their impact on this contact-induced linguistic phenomenon.

\subsection{Mass media and information technology}

Our $21^{\text {st }}$-century experience is profoundly affected by contact with foreign cultures. Because of the impact that the mass media, the Internet, on-line platforms and advertising have on our everyday lives, it is undeniable that we have never been more exposed to new cultures and, consequently, new languages (Muñoz-Basols, Adrjan and David 2013, 160). Although the process of languages influencing one another has existed for centuries, it is true that this phenomenon has become more evident with our immediate access to information and the constant emergence of new vocabulary from new areas of knowledge. We need only to watch or read the news to notice this. Recently, for instance, we have become used to hearing and reading foreign-sounding references in the media, such as the topical Spanish words corralito or indignados in the English-language press, and hooligan and credit crunch in Spanishlanguage news outlets.

Much has been written about how global mass consumption of English-language media has led to the Anglicization of languages all over the world. However, it must be pointed out that mass media and information technology also contribute to the rapid adoption of foreignisms into English, and this is especially true of Hispanicisms. In the same manner that Spanish absorbs Anglicisms, Spanish lexis is exported to English through popular culture products such as television, films and music. This influence is made even greater by the evergrowing presence of Hispanics in the U.S. and the linguistic phenomena this entails, particularly bilingualism and code-switching (Potowski and Rothman 2011), as well as translanguaging (García and Wei 2014). People watching a TV programme in which Spanish words are used (e.g., the children's show Dora the Explorer or the Sesame Street segment called 'The Spanish Word of the Day') get exposure to words and catchphrases from this language. In addition, the use of the Spanish language in popular culture is, in the case of the 
U.S., inextricably related to the notion of identity in Hispanic and Latino culture (see Montilla 2013, Rojas and Piñón 2014).

Selected, often pre-packaged words and catchphrases from TV are used to encapsulate a linguistic and cultural representation that exposes English speakers to lexical units that they might never have heard otherwise, and which they may even reproduce in the future. For this reason, it is not surprising to hear in these TV programmes genuine Spanish words like nada, mucho, quiero, bueno, chica, vámonos, and cuidado, or distorted ones such as no problemo, which can also be considered examples of "mock Spanish" (Moreno Fernández 2014, 19). A quick search in the Corpus of American Soap Operas (2001-2012) (Davies 2012) reveals 218 occurrences for nada, 89 for mucho, 43 for quiero, 41 for bueno, 32 for no problemo, 26 for chica, 15 for cuidado and 14 for vámonos. This includes instances of speech in either an English or a Spanish-speaking context or a mixture of both.

The rise of "mock Spanish" constitutes another interesting new phenomenon in English (see Callahan 2014). These are not actual loanwords, but rather coinages formed on the basis of phonetic similarity with Spanish terms (Rodríguez González 2001). The OED, for instance, defines the word $e l$ as

the initial element of jocular, pseudo-Spanish noun and [adjective] phrases representing [colloquial] (and often nonce) alternatives to their English bases (nouns or [adjectives frequently] in turn suffixed by the Spanish [masculine] ending -o), which convey disparagement, emphasis, or amusement: as el cheapo, el creepo, el foldo, el smoggo, etc. (OED 2014).

This type of hybrid construction that employs morphological features of both languages can be regarded as a linguistic mechanism for displaying foreignness, especially within a humorous context (see Muñoz-Basols, Adrjan and David 2013). An analogous phenomenon in Spanish can be seen in the Anglicisation of native words through the addition of the -ing suffix, as in the brand names Vueling, a Spanish low-cost airline, and Bicing, a bicycle sharing system in the city of Barcelona, and fashionable neologisms like puenting, bungee jumping,' and sofing or tumbing (Sanz Hernández 2007, 148), two colloquial terms popularised in Spain through advertising with the meaning of 'to lie down.' Spanish speakers automatically associate the -ing morpheme with English, along with the perception of trendiness and modernity that comes with the language.

\subsection{Attitudes to foreignisms}

This frequent exposure to new languages, sounds and intonations that we perceive as foreign and yet integrate consciously or subconsciously into our own culture and language, may lead us to adopt different attitudes and perceptions. For some speakers, new lexical units may sound familiar depending on the degree of exposure they may have had to a particular language or culture. For others, they may prove exotic, even fun, or simply unpronounceable, making it difficult to remember how to pronounce them or remember their actual meaning.

In order to understand each language's attitude, we must also examine the notion of language purism. As Payne $(2010,64)$ notes, "The fact that English is particularly permeable to such influences is probably due to the history of English as a lingua franca for over 1500 years, and the lack of an 'English Language Academy' to defend the language against outside influences."

This is not to say that the history of English has been entirely free of purist attitudes. Particularly notable was the debate that raged during the Early Modern period around "inkhorn terms," or words of Latin, Italian or French extraction used by $16^{\text {th }}$-century academics to address the inadequacies they perceived in English vocabulary (Guijarro Ojeda 
and Ruiz Cecilia 2004). Purists viewed these new-fangled terms as signs of linguistic decadence, and protested against them for their novelty and obscurity. However, as Durkin $(2014,318)$ notes, purism was unable to assert as much influence on the lexical development of Early Modern English as it had on other Germanic languages during the same period, and the same can be said of other instances of purist reactions that occurred in every succeeding century (Guijarro Ojeda and Ruiz Cecilia 2004).

In fact, what would English be today without words such as coup d'état, guru or guerrilla, all belonging to different languages in origin, kept intact as far as their orthographic conventions are concerned, but which help the English speaker to express concepts that would otherwise be difficult to articulate in a precise and economical manner? As we have seen in the previous analysis, foreign words have been entering English throughout the centuries for many reasons, including practicality and semantic precision, with many eventually no longer perceived as foreign with the passage of time. As mentioned above, not having an English Language Academy might have been one of the factors that allowed the English language to behave in a more permissive way than Spanish, with relatively less purism and allowing for a greater number of terms to be adopted or integrated into the language.

The case of Spanish is very different. Like many other languages such as French, German, Italian, Icelandic, Japanese, etc., Spanish has been greatly influenced by English and has acquired a growing body of words from this language. However, the Real Academia Española (RAE), has since its establishment in 1713 been exerting linguistic protectionism, i.e., imposing restrictions on certain words to be adopted, accepting some of them temporarily while getting rid of others, or making numerous modifications in the revisions to its dictionary, the Diccionario de la lengua española (DRAE). One of the most common ways in which the RAE has applied linguistic purism to foreign words in its dictionary has been through phonological and orthographic adaptation, a policy which contrasts with the one generally applied to foreignisms in the $\mathrm{OED}$, e.g., tête-à-tête, gemütlichkeit, terra-cotta, etc. This can be easily perceived in words such as bluyín, 'blue jean,' cóctel 'cocktail,' champú 'shampoo,' guachimán 'watchman,' güisqui, 'whisky,' and yate 'yacht' or more recently baipás 'by-pass.' A few words that have been incorporated in this way have also become derivationally productive, as, for example, líder, which gave rise to liderar and liderazgo; and gol, which spun off goleada, golazo, golear and goleador (Dworkin, 2012, 224). These words, and many others, were adapted to the pronunciation and spelling conventions of Spanish in an attempt to smooth their transition into the speaker's repertoire. It is undeniable that in using these words with such transformation the speaker easily loses track of their etymological origin.

Some of these examples may illustrate diatopic variation among Spanish-speaking countries. For instance, both the DRAE and the Diccionario de americanismos (DA) register the calque guachimán 'watchman' as an adaptation from English. Both dictionaries point out that this term is not used in Spain, although it is common in many Latin American countries.

And yet the influx of English loans continues despite the negative purist reaction, not only of the RAE, but also of many Spanish writers and intellectuals, who have described Anglicisms in such derogatory terms as "plaga" (Mallo 1954, 135) and "injuria" (Pérez de Pablos 1999). The acceptance of Anglicisms into various editions of the DRAE is almost always met with harsh criticism from those sections of Spanish society who see this encroachment of English words and meanings as a threat to the purity and integrity of their language (Dworkin 2012). Cases like espectáculo for 'show,' existencias for 'stock,' superventas for 'bestseller,' and mercadotecnia for 'marketing,' also illustrate that there are negative feelings towards Anglicisms that are positioned to replace what are deemed to be perfectly adequate Spanish signifiers. However, prominent members of the Real Academia 
such as Emilio Lorenzo, Rafael Lapesa and Manuel Seco have over the years expressed a more permissive attitude towards Hispanic Anglicisms (see Rodríguez González 1999, Rodríguez Medina 2000).

\subsection{Dictionaries and official linguistic policy}

Linguistic policy often comes into play in making decisions as to which foreignisms can be accepted into a language. According to Shapiro (1989, 23), even while understanding purism, one needs to reject the traditional idea of language as a neutral medium of communication and, instead, begin to see language as "discourse." This is precisely what the late philologist and Academy member Fernando Lázaro Carreter seemed to suggest in a speech given at the Escuela de Lexicografía Hispánica on neologisms, while referring to the $22^{\text {nd }}$ edition of the DRAE published in 2001. In his words, one can perceive how the Spanish language is felt to be in an inferior position in comparison to English:

La aparición de unos cuantos cientos de voces extranjeras en la vigésima segunda edición del Diccionario académico, aun impresas con la cursiva que las señala como forasteras, ha producido algunas reacciones poco complacidas, incluso entre quienes cada día se ponen un slip, y no unos calzoncillos, o se introducen en unos pantys y no en unas medias, sin sentir que, llamándolos así, están ofendiendo gravemente el honor, tal vez la esencia de nuestras respectivas comunidades encarnada en la lengua. Y lo hacen, a veces, haciendo gestos de escándalo porque la Academia ha incrustado en las columnas de su diccionario esos huéspedes aunque los resalte con la señal de alarma que son los caracteres itálicos (Lázaro Carreter 2002, 1).

As Lázaro Carreter explains, the use of italics in the DRAE functions as a reminder, "an alert," of the fact that the term is foreign, thereby clearly "branding" it as belonging to a different category and "on hold": that is, waiting for the Academy members to decide whether to include them or not in the next revision of the dictionary. By contrast, the absence of italics means the opposite, that a word is accepted as such without added connotations.

The Oxford English Dictionary (OED), the foremost authority on the English language, is now undergoing its first comprehensive revision since its first edition was published in 1928. Although the OED is primarily a historical and descriptive dictionary, and not a prescriptive one like the DRAE, its changing policies towards words of non-British origin is an indication of the particular challenges that foreignisms pose for dictionary editors. An alert in the form of tramlines, or two parallel lines beside the headword $(\|)$, was initially used to brand words considered alien to English, but this practice has long been abandoned. As English began to spread beyond the borders of Britain and the language began to borrow words from every shore that it reached, the OED moved towards a more open policy regarding lexical importations of all kinds, although there are still improvements that need to be made in order to ensure balanced coverage of words of non-British origin in the dictionary (Salazar 2014).

Regarding the DRAE, the current policy on extranjerismos, or foreign words, is explained on the website of the Diccionario panhispánico de dudas (DPD), a dictionary of the RAE first published in 2005 that clarifies the usage of terms deemed problematic (see Paffey 2012, 62-63), and which can be summarised as the following:

1. Superfluous or unnecessary foreign words (extranjerismos superfluos o innecesarios). These are words that according to the RAE possess an equivalent in Spanish, such as the 
examples provided on its website, e.g., the use of the words back-up and consulting instead of their equivalents copia de seguridad and consultoría.

2. Needed and widely used foreign words (extranjerismos necesarios o muy extendidos). These include words for which there is either no equivalent, or one that is difficult to find, e.g., blues, jazz. If they have not been formally adapted, they should be written in italics or in quotation marks. If, on the other hand, they can be adapted, there is the choice of either maintaining their original spelling but pronounced $a$ la española (as if they were Spanish), e.g., airbag 'airbag,' and consequently with a written accent when needed, e.g., máster; or they can maintain their original pronunciation by following the written conventions of the Spanish language, e.g., pádel 'paddle,' béisbol 'baseball.'

Clearly, the OED and the DRAE have different ways of providing information about foreignisms to their users which are reflective of their divergent attitudes. What is interesting is that by providing different types of information about foreign words, these dictionaries may also be conditioning, influencing or even determining the perceptions of speakers. The word shorts, for instance, despite being widely used and remaining as an entry in the $23^{\text {rd }}$ edition of the DRAE published in October 2014, is catalogued as an anglicismo innecesario (unnecessary Anglicism) by the DPD, which recommends using other alternatives for shorts such as pantalón corto or pantalones cortos.

A different case is the word stock, clearly marked in italics as a foreign word in the $23^{\text {rd }}$ edition of the DRAE. While the DPD acknowledges this as a frequently used word, labelling it as an anglicismo evitable (avoidable Anglicism), its recommendation is to employ expressions such as existencias, mercancías almacenadas or en depósito instead.

It is important to note that the latest edition of the DRAE has included the use of the word tableta to signify a new technological device, defining it as "dispositivo eléctronico portátil con pantalla táctil y con múltiples prestaciones" $(2014,2066)$, but without making any explicit reference to the fact that this is an adaptation of the English term tablet, or acknowledging that both tablet and tableta coexist in the vocabulary of Spanish speakers.

Another more recent example that illustrates the attitude towards Anglicisms displayed by different institutions is the word selfie, first used in Australian English in 2002, which has been incorporated into many languages. The Fundación del Español Urgente (Fundéu), an institution created to monitor the use of Spanish, especially in the mass media, recommends using the Spanish alternative autofoto to refer to the action of taking a picture of oneself with a digital device.

These four examples illustrate various attitudes and perceptions on vocabulary use. Some speakers might have reservations about putting on shorts, while others may resist getting rid of their stock. Similarly, in a few years we will find out if speakers end up using both tablet and tableta, selfie and autofoto, or if one of the two terms will prevail over the other, because it will have been incorporated more easily into the language, or because of the recommendation of the RAE or of another language institution, or because of how these terms are used in the mass media.

In any case, the $23^{\text {rd }}$ edition of the dictionary seems to have taken the opportunity to include new words used in Latin America in an attempt to better reflect the reality of a language spoken on both sides of the Atlantic, as well as words from Equatorial Guinea and the Philippines. In this sense, the inclusion of the term estadounidismo (Bazán-Figueras and Figueras 2014, Lynch and Potowski 2014) is certainly remarkable, i.e., "palabra o uso propios del español hablado en los Estados Unidos de América" (DRAE 2014, 961). In the latest edition of the dictionary, only five entries are given this new label: congresional 'congressional' (Ant., Col., EE.UU., Nic.), guardavidas 'lifeguard' (Arg., Chile, C. Rica, 
EE.UU., Nic., Pan., Par., Ur.), sobador 'uncertified chiropractor' (Am. Cen., Ec., EE.UU., Perú), billón 'billion' (EE.UU) and trillón 'trillion' (EE.UU) (Dumitrescu 2014), the last two numerical terms being the only ones exclusively labelled as estadounidismos, as well as the only calques from English both at the notional and lexical level. This leads one to wonder why widely used calques in US Spanish such as aplicar 'to apply,' departamento 'department,' and eligible 'eligible,' undeniably present in the legal and administrative spheres, have not been given the same attention. It remains to be seen whether the treatment of Anglicisms is the same in future updates of the DRAE, and whether the policy towards words borrowed from English is influenced, or even determined, by the increasing body of estadounidismos and language contact situations in general between English and Spanish in the United States, as it has briefly been sketched out here.

\section{Conclusions}

In this article we have introduced a new definition for cross-linguistic lexical influence and demonstrated the utility of this concept by studying reciprocal borrowing between Spanish and English. By taking this comparative approach, we have shown how the influence of one language on the word stock of another is a reflection of social history, dominant trends in technology and communication, and prevalent attitudes to foreign words.

Through a comparative analysis of cross-linguistic lexical influence, we have shown how two of the most widely spoken languages, English and Spanish, have influenced one another at the lexical level over the centuries. The chronological analysis has also allowed us to get an insight into the most common semantic fields from which words were imported into each language in various time periods. We have analysed some of the historical and social factors that may have favoured cross-linguistic lexical influence and considered how the mass media and information technology contribute to the rapid dissemination of words in both languages. In the same analysis we have also highlighted some of the speakers' and institutional attitudes towards foreignisms, which can be perceived in the selection and the use of specific lexical units. Finally, we have made a brief incursion into two of the most comprehensive dictionaries for both languages, the Oxford English Dictionary and the Diccionario de la lengua española, in order to raise the question of how their linguistic policies may affect the manner in which foreignisms are incorporated into each language.

By basing part of this study on information garnered from lexicographical resources such as the OED, we have has also underscored the value of historical data in investigations of cross-linguistic lexical influence. Such information provides a quantitative foundation for observing how a language adapts to new realities, and how contact with other languages impacts this constant evolution. Access to quantitative historical evidence of lexical borrowing in Spanish is still limited, especially in comparison to what is available for English. The hope is that further development of the RAE's Nuevo diccionario histórico del español (NDHE) will one day fill this gap.

It would be useful for future research to concentrate on studying further differences between the OED and the DRAE, tracing how these lexical resources were initially configured since their creation, what their raison d'être was, and how they have evolved since entering the digital age. Such research would certainly contribute to clarifying how these two language tools, and their respective developments and policies, may have determined, or even conditioned, lexical borrowing between English and Spanish, and what additional information they can reveal regarding attitudes about lexical borrowing between the two languages. 


\section{Acknowledgements}

We would like to thank Philip Durkin, deputy chief editor of the Oxford English Dictionary, for his valuable input during the conduct of this study. We are also grateful to the two anonymous reviewers and to Pawel Adrjan, Marianne David and Daniel Hayes for their helpful comments and suggestions. Javier Muñoz-Basols acknowledges funding from the Spanish Ministry of Science and Innovation (grant: EDU2014-57677-C2-1-R).

\section{References}

Algeo, John. 1996. "Spanish Loanwords in English by 1900." In Spanish Loanwords in the English Language: A Tendency towards Hegemony Reversal, edited by Félix Rodríguez González, 19-40. The Hague: Mouton de Gruyter.

Asociación de Academias de la Lengua Española. 2010. Diccionario de americanismos [Dictionary of Americanisms]. 1st ed. Madrid: Santillana. Also available at http://www.asale.org/recursos/diccionarios/damer. Accessed 6 August 2014.

Bazán-Figueras, Patricia, and Salvador J. Figueras. 2014. "The Future of Spanglish: Global or Tribal?" Perspectives on Global Development and Technology (13) 1-2: 261-266.

Boletín de Información Linguiística de la Real Academia Española (BILRAE). 2013. "Tecnicismos, neologismos y extranjerismos en el español [Technicisms, neologisms and foreignisms in Spanish]": 1-9.

http://www.rae.es/sites/default/files/TecnicismosNeologismosExtranjerismos.pdf. Accessed 7 November 2014.

Braunmüller, Kurt, and Juliane House. 2009. Convergence and Divergence in Language Contact Situations. Amsterdam: John Benjamins.

Callahan, Laura. 2014. "The Importance of Being Earnest: Mock Spanish, Mass Media, and the Implications for Language Learners.” Spanish in Context 11 (2): 202-220.

Cannon, Garland. 1996. "Recent Borrowings from Spanish into English.” In Spanish Loanwords in the English Language: A Tendency towards Hegemony Reversal, edited by Félix Rodríguez González, 41-60. The Hague: Mouton de Gruyter.

Cenoz, Jasone. 2000. "Research on Multilingual Acquisition." In English in Europe: The Acquisition of a Third Language, edited by Jasone Cenoz and Ulrike Jessner, 39-53. Clevedon: Multilingual Matters.

Cenoz, Jasone. 2001. "The Effect of Linguistic Distance, L2 Status and Age on CrossLinguistic Influence in Third Language Acquisition." In Cross-Linguistic Influence in Third Language Acquisition: Psycholinguistic Perspectives, edited by Jasone Cenoz, Britta Hufeisen, and Ulrike Jessner. Clevedon: Multilingual Matters.

Cenoz, Jasone, Britta Hufeisen, and Ulrike Jessner (eds). 2001. Cross-Linguistic Influence in Third Language Acquisition: Psycholinguistic Perspectives. Clevedon: Multilingual Matters.

Cuervo, Rufino José. 1907. Apuntaciones críticas sobre el lenguaje bogotano con frecuente referencia al de los países de Hispano-América [Critical notes on the language of Bogota with frequent reference to Spanish American countries]. 5th ed. Paris: R. Roger et Chernoviz.

David, Marianne and Javier Muñoz-Basols. 2011. "Defining and Re-Defining Diaspora: An Unstable Concept." In Defining and Re-Defining Diaspora: From Theory to Reality, edited by Marianne David and Javier Muñoz-Basols, xii-xxiv. Oxford: InterDisciplinary Press.

Davies, Mark. Corpus of American Soap Operas (2001-2012). 2012. http://corpus2.byu.edu/soap/. Accessed 6 August 2014. 
Dumitrescu, Domnita. 2013. "El español en Estados Unidos a la luz del censo de 2010: los retos de las próximas décadas [Spanish in the United States in light of the 2010 census: the challenge of the coming decades]." Hispania 96 (3): 525-541.

Dumitrescu, Domnita. 2014. "Sobre el así-llamado Spanglish y el concepto de 'estadounidismos' [On the so-called Spanglish and the concept of 'estadounidismos']." Paper delivered at the American Association of Teachers of Spanish and Portuguese Southern California Chapter (AATSPSoCal), 25 October, University of Southern California.

Durkin, Philip. 2014. Borrowed Words: A History of Loanwords in English. Oxford: Oxford University Press.

Dworkin, Steven N. 2012. A History of the Spanish Lexicon: A Linguistic Perspective. Oxford: Oxford University Press.

Eggington William, and Helen Wren (eds). 1997. Language Policy: Dominant English, Pluralist Challenges. Amsterdam: John Benjamins.

García, Ofelia, and Li Wei. 2014. Translanguaging: Language, Bilingualism and Education. New York: Palgrave Macmillan.

Gooch, Anthony. 1996. "Aspects of the Incidence of Hispanicisms in British English: A Study in Language, History, Politics and Psychology." In Spanish Loanwords in the English Language: A Tendency towards Hegemony Reversal, edited by Félix Rodríguez González, 231-251. The Hague: Mouton de Gruyter.

Guijarro Ojeda, Juan Ramón, and Raúl Ruiz Cecilia. 2004. "Attitudes of English People towards Lexical Borrowing." Glosas Didácticas 11: 215-220.

Hall, Christopher, and Peter Ecke. 2002. "Parasitism as a Default Mechanism in L3 Vocabulary Acquisition." In The Multilingual Lexicon, edited by Jasone Cenoz, Britta Hufeisen, and Ulrike Jessner, 71-86. New York: Kluwer.

Hildebrandt, Martha. 1961. La lengua de Bolivvar [The language of Bolivar]. Caracas: Universidad Central de Venezuela.

Hulk, Aafke, and Natascha Müller. 2001. "Bilingual First Language Acquisition at the Interface between Syntax and Pragmatics." Bilingualism: Language and Cognition 3 (3): $227-244$.

Instituto de Investigación Rafael Lapesa de la Real Academia Española. 2013. Nuevo diccionario histórico del español (NDHE) [New historical dictionary of Spanish]. http://web.frl.es/DH/

Jansen, Silke. 2005. Sprachliches Lehngut im world wide web: Neologismen in der französischen und spanischen Internetterminologie [Linguistic borrowing in the World Wide Web: neologisms in French and Spanish Internet terminology]. Tübingen: Gunter Narr.

Lázaro Carreter, Fernando. 2002. "El neologismo en el DRAE [Neologisms in the DRAE]." Inauguración del I Curso de la Escuela de Lexicografía Hispánica, 15 February. http://www.rae.es/noticias/inauguracion-del-i-curso-de-la-escuela-de-lexicografiahispanica. Accessed 1 August 2014.

Lira Urquieta, Pedro. 1973. Estudios sobre vocabulario [Studies on vocabulary]. Santiago de Chile: Editorial Andrés Bello.

Lodares, Juan Ramón. 1996. "Hispanic Tracks in English: Cowboys and Gold-rushers in the Old West." In Spanish Loanwords in the English Language: A Tendency towards Hegemony Reversal, edited by Félix Rodríguez González, 157-176. The Hague: Mouton de Gruyter.

Lorenzo, Emilio. 1996. Anglicismos hispánicos [Hispanic Anglicisms]. Madrid: Gredos. 
Lukin, Tomás. 2014. "No hubo stay y no hay default [There was no stay and there is no default]." Página 12, 31 July. http://www.pagina12.com.ar/diario/principal/diario/index2014-07-31.html.

Lynch, Andrew, and Kim Potowski. 2014. "La valoración del habla bilingüe en los Estados Unidos: fundamentos sociolingüísticos y pedagógicos en Hablando bien se entiende la gente" [The evaluation of bilingual speech in the United States: Sociolinguistic and pedagogic foundations in Hablando bien se entiende la gente]. Hispania 97 (1): 32-46.

Mallo, Jerónimo. 1954. "La plaga de los anglicismos [The plague of Anglicisms]." Hispania 37: 135-140.

Medina López, Javier. 2004. El anglicismo en el español actual [Anglicisms in current Spanish]. 2nd ed. Madrid: Arco Libros.

Montilla, Patricia M. 2013. Latinos and American Popular Culture. Santa Barbara: Praeger.

Moreno Fernández, Francisco. 2014. "El idioma en la escuela estadounidense [Language in US schools]." ABC, 3 August. http://www.abc.es/cultura/20140804/abci-idiomaescuela-estadounidense-201408031754.html. Accessed 6 August 2014.

Muñoz-Basols, Javier, Pawel Adrjan, and Marianne David. 2013. "Phonological Humor as Perception and Representation of Foreignness." In Irony and Humor: From Pragmatics to Discourse, edited by Leonor Ruiz Gurillo and Belén Alvarado Ortega, 159-188. Amsterdam: John Benjamins. doi: 10.1075/pbns.231.10bas

Muñoz-Basols, Javier, Micaela Muñoz-Calvo, and Jesús Suárez García. 2014. "Hacia una internacionalización del discurso sobre la enseñanza del español como lengua extranjera [Towards an internationalization of the discourse on the teaching of Spanish as a foreign language]." Journal of Spanish Language Teaching 1 (1): 1-14. doi: 10.1080/23247797.2014.918402

Odlin, Terence. 1989. Language Transfer: Cross-Linguistic Influence in Language Learning. Cambridge: Cambridge University Press.

Paffey, Darren. 2012. Language Ideologies and the Globalization of 'Standard' Spanish. London and New York: Bloomsbury.

Páramo García, Félix. 2003. Anglicismos léxicos en traducciones inglés-español 1750-1800 [Lexical Anglicisms in English-Spanish translations 1750-1800]. León: Junta de Castilla y León.

Payne, Thomas E. 2010. Understanding English Grammar: A Linguistic Introduction. Cambridge: Cambridge University Press.

Penny, Ralph John. 2006. Gramática histórica del español [Historical grammar of Spanish]. Barcelona: Ariel.

Pérez de Pablos, Susana. 1999. "García de la Concha alerta sobre el uso de anglicismos y el empobrecimiento del lenguaje [García de la Concha warns against the use of Anglicisms and the impoverishment of language]." El País, July 6. http://elpais.com/diario/1999/07/06/cultura/931212003_850215.html Accessed 6 August 2014.

Pichardo, Esteban. 1836. Diccionario provincial de voces cubanas [Provincial dictionary of Cuban words]. Havana: Imprenta de la Real Marina.

Potowski, Kim, and Jason Rothman (eds). 2011. Bilingual Youth: Spanish in EnglishSpeaking Societies. Amsterdam: John Benjamins.

Pratt, Chris. 1980. El anglicismo en el español peninsular contemporáneo [Anglicisms in contemporary Peninsular Spanish]. Madrid: Gredos.

Real Academia Española. 2001. Diccionario de la lengua española [Dictionary of the Spanish language]. 22nd ed. Madrid: Espasa. Also available at http://www.rae.es/recursos/diccionarios/drae. Accessed 6 August 2014. 
Real Academia Española. 2003. Diccionario de la lengua española [Dictionary of the Spanish language]. CD-ROM. 22nd ed. Madrid: Espasa.

Real Academia Española. Diccionario panhispánico de dudas [Panhispanic dictionary of doubts]. http://www.rae.es/recursos/diccionarios/dpd. Accessed 6 August 2014

Real Academia Española. 2014. Diccionario de la lengua española [Dictionary of the Spanish language]. 23rd ed. Madrid: Espasa.

Real Academia Española. Nuevo tesoro lexicográfico de la lengua española $[\mathrm{New}$ lexicographical treasure of the Spanish language]. http://ntlle.rae.es/ntlle/SrvltGUILoginNtlle. Accessed 6 August 2014.

Rodríguez González, Félix. 1995. "Spanish Influence on English Word-Formation. The Suffix -Ista.” American Speech 70 (4): 421-429.

Rodríguez González, Félix (ed). 1996a. Spanish Loanwords in the English Language: A Tendency towards Hegemony Reversal. The Hague: Mouton de Gruyter.

Rodríguez González, Félix. 1996b. "Functions of Anglicisms in Contemporary Spanish." Cahiers de lexicologie 68 (1): 107-128.

Rodríguez González, Félix. 1999. "Anglicisms in Contemporary Spanish: An Overview." Atlantis 21: 103-109.

Rodríguez González, Félix. 2001. "Spanish Contribution to American English Wordstock: An Overview." Atlantis: Journal of the Spanish Association of Anglo-American Studies 23 (2): 83-90.

Rodríguez González, Félix. 2002. "Anglicismos y calcos en el español actual [Anglicisms and calques in current Spanish]." In L'inglese e le altre lingue europee: studi sull'interferenza linguistica [English and other European languages: studies on linguistic interference], edited by Félix San Vicente, 149-169. Bologna: Clueb.

Rodríguez Medina, María Jesús. 2000. "El anglicismo en español: Revisión crítica del estado de la cuestión [Anglicisms in Spanish: Critical review of the state of the art]." Philologia Hispalensis 14: 99-112.

Rojas, Viviana, and Juan Piñón. 2014. "Spanish, English or Spanglish? Media Strategies and Corporate Struggles to Reach the Second and Later Generations of Latinos." International Journal of Hispanic Media 7: 1-15.

Salazar, Danica. 2014. "Towards Improved Coverage of Southeast Asian Englishes in the Oxford English Dictionary." Lexicography: Journal of Asialex 1 (1): 95-108.

Sanz Hernández, Alexia. 2007. El consumo de la cultura rural. Zaragoza: Prensas Universitarias de Zaragoza.

Shapiro, Michael J. 1989. “A Political Approach to Language Purism.” In The Politics of Language Purism,ed. by Björn H. Jernudd and Michael J. Shapiro, 21-30. Berlin: Mouton de Gruyter.

Sharwood-Smith, Michael, and Eric Kellerman. 1986. "Crosslinguistic Influence in Second Language: An Introduction.” In Crosslinguistic Influence in Second Language Acquisition, edited by Michael Sharwood-Smith and Eric Kellerman, 1-9. Oxford: Pergamon.

The Oxford English Dictionary. 2000. 3rd ed. http://www.oed.com. Accessed 15 June 2015.

Authors' address:

Javier Muñoz-Basols

Faculty of Medieval and Modern Languages

University of Oxford

41 Wellington Square

Oxford OX1 2JF

United Kingdom 
javier.munoz-basols@mod-langs.ox.ac.uk

Danica Salazar

Oxford English Dictionary

Oxford University Press

Great Clarendon Street

Oxford OX2 6DP

United Kingdom

danica.salazar@oup.com

Received: May 7, 2014

Final revision received: August 30, 2014

Accepted: August 30, 2014 